\title{
FAKTOR - FAKTOR YANG BERHUBUNGAN DENGAN TIMBULNYA GEJALA GASTRITIS PADA SISWA SEKOLAH MENENGAH ATAS KOTA JAMBI
}

\author{
Rahmawati $^{12}$
}

\begin{abstract}
Gastritis is an inflammation of the gastric mucosa that can be acute, chronic, diffuse or localized, the stomach is a digestive device that functions mechanically in storing food and drinks, breaking food into small particles, mixing with gastric fluid and gradually entering the intestine. The clinical picture of erosive acute gastritis varies from mild, asymptomatic, to very severe. Factors for gastritis are foods contaminated with bacteria, caffeine-containing drinks, alcohol, drugs such as non-steroidal anti-inflammatory drugs aspirin, acidic foods and drinks, spicy foods, and irregular diets. This research is an analytical study with a cross sectional approach. The sample of this study were students from Jambi City High School who were randomly drawn to get 930 samples. The results obtained from 930 respondents, most (61.3\%) had chronic gastritis. And found a significant relationship between diet and the onset of symptoms of acute and chronic gastritis with P-Value $=0,000$. Based on the results of this study, the researchers expect health information, especially regarding gastritis by local health workers so as to reduce the incidence of acute and chronic gastritis.
\end{abstract}

Keywords: Acute Gastritis, Chronic Gastritis, Gastritis Factors

\section{PENDAHULUAN}

Tubuh manusisa terdiri dari 50 juta sel, junlah panjang jaringan pembuluh darahnya sampai $100.000 \mathrm{~km}$ dan lebih dari 500 macam proses kimiawi terjadi di dalam hati. Tanpa kita sadari, tubuh mengatur suhu tubuh, tekanan udara, penegak dan penggerak, transportasi, pernapasan, pencernaan. Sistem pencernaan dapat mengalami ganguan seperti radang atau infeksi. Radang atau infeksi pada dinding lambung disebut sebagai gastritis (Irianto, 2014).

Gastritis merupakan penyakit tunggal, tetapi terbentuk dari beberapa kondisi yang kemudian mengakibatkan peradangan pada lambung. Pada beberapa kasus, gastritis sapat menyebabkan terjadinya borok (ulcer)dan dapat meningkatkan resiko dari kanker lambung.

${ }^{12}$ Dosen Program Studi Keperawatan Akper Jambi 
Akan tetapi bagi banyak orang gastritis bukanlah penyakit yang serius dan dapat segera membaik dengan pengobatan (Republika, 2015)

Penyakit gastritis sering terjadi pada remaja, orang - orang yang stres, karena stres dapat meningkatkan produksi asam lambung, pengkonsumsian alkohol dan obat - obatan anti inflamasi non steroid. Gejala yang timbul pada penyakit gastritis adalah rasa tidak enak pada perut, perut kembung, sakit kepala, lidah berlapis. Penyakit gastritis sangat mengganggu aktifitas sehari - hari karena penderita akan merasa nyeri dan rasa sakit pada perut. Selain dapat menyebabkan rasa tidak enak, juga menyebabkan peresaran saluran cerna atas, ulkus, anemia karena gangguan absorbsi vitamin B12 (Supriatmo, 2013).

Gejala - gejala penyakit gastritis dapat dikenali pula dengan rasa perih, sakit terbakar pada perut bagian atas yang dapat menjadi lebih baik atau lebih buruk ketika makan. Slain itu penderita juga biasanya mengeluh gejala mual, muntah, kehilanagan selera makan, kembung, perih terasa penuh di abgian atas setelah makan dan hingga kehilanga berat badan (Republika, 2015).

Gambaran klinis gastritis akut erosif dangat bervariasi, mulai dari yang sangat ringan sampai yang berat yang dapat membawa kematian. Ada sebagian besar kasus, gejalanya amat ringan bahkan asimtomatik, keluhan - keluhan itu misalnya nyeri timbul pada ulu ati biasanya ringan dan tidak dapat di tunjukkan dengan tepat lokasinya, kadang - kadang disertai mual dan muntah (Hirlan dkk, 2012).

Gastritis akut dapat disebabkan oleh endotoksin bakteri, alkohol, aspirin merupakan agen - agen penyebab yang sering, obat obatan seperti NSAID juga terlibat. Makan tidak teratur dan beberapa makanan berbubu, termasuk lada, cuka atau mustard, dapat menyebabkan gejala yang mengarah pada gastritis.

Faktor psikologis stres baik primer maupun sekunder dapat merangsang peningkatan produksi asam - asam gerakan peristaltik lambung. Stres juga mendorong gerakan antara makanan dan dinding lambung menjadi tambah kuat yang dapat menyebabkan luka pada dinding lambung. Pada kasus gastritis faktor penyimpangan makan merupakan titik awal yang mempengaruhi terjadinya perubahan dinding lambung. Peningkatan asam lambung dapat di rangsang oleh konsumsi makanan dan minuman, cuka, cabai, kopi, alkohol serta makanan lain yang bersifat merangsang dinding lambung (Vera U, 2015).

Berdasarkan data dari dinas kesehatan kota Jambi bahwa jumlah penderita gastritis terjadinya peningkatan tiap tahunnya yaitu pada tahun 2017 mencapai angka 15. 057 orang dimana terjadi peningkatan sebanyak kurang lebih $7,5 \%$ tiap tahunnya selama tiga tahun terakhir. 
Survey awal penelitian ini dilakukan pada tanggal 6 Juni 2017 di tempat para remaja - remaja sering berkumpul (taman remaja, taman jomblo). Setelah dilakukan wawancara para remaja saat ini memiliki banyak sekali kegiatan-kegiatan ekstrakurikuler yang diadakan oleh sekolah seperti pramuka, les, theater, basket, dan paskibraka. Ditambah lagi dengan pembagian jadwal masuk sekolah pagi dan siang untuk beberapa sekolah. Jadwal sekolah pagi siswa harus sudah berada di sekolah jam 06.45 WIB yang menurut pengakuan mereka di setiap hari tidak selalu melakukan sarapan, mereka menganggap bahwa sarapan bisa dilakukan pada waktu jam istirahat. Beberapa remaja juga menyampaikan bahwa ada beberapa mata pelajaran yang terpisah dari jadwal pelajaran yang sudah ada seperti pelajaran komputer dan penjaskes jadi mahasiswa harus menambah waktu untuk melakukan kegiatan tersebut pada siang hari setelah pulang sekolah. Hal ini membuat para remaja siswa - siswi SMA melupakan pola makan yang teratur dan jenis makanan yang baik. Kantin sekolah menyediakan menu nasi goreng, bakso, mie ayam, tekwan, sate. Jenis makanan inilah yang mau tidak mau dikonsumsi oleh siswa - siswa SMA.

Penelitian ini bertujuan untuk mengetahui faktor - faktor yang berhubungan dengan timbulnya gastritis pada siswa - siswa Sekolah Menengah Atas di Kota Jambi. Dimana faktor - faktor tersebut adalah pola makan dan jenis makanan.

\section{METODE PENELITIAN}

Penelitian ini merupakan penelitian analitik dengan menggunakan rancangan cross sectional. Yang bertujuan untuk melihat korelasi antara variabel independen dan variabel dependen pada waktu yang bersamaan.

Populasi pada penelitian ini adalah seluruh siswa - siswa Sekolah Menengah Atas yang ada di Kota Jambi dan di dapatkan sampel sebanyak 930 orang sampel. Pengambilan sampel menggunakan teknik simple random sampling dengan menggunakan nomor undian yang dipilih secara acak.

\section{HASIL DAN PEMBAHASAN}

1. Karakteristik Responden

Tabel 1. Distribusi Frekuensi Responden Berdasarkan Jenis Kelamin

\begin{tabular}{|l|c|c|}
\hline \multicolumn{1}{|c|}{ Jenis Kelamin } & Frekuensi & Persentase (\%) \\
\hline Laki - laki & 370 & 39,8 \\
\hline Perempuan & 560 & 60,2 \\
\hline Total & 930 & 100 \\
\hline
\end{tabular}

Berdasarkan tabel 1 dapat diketahui bahwa sebagian besar responden berjenis kelamin perempuan $60,2 \%$. 
Tabel 2. Distribusi Frekuensi Responden Berdasarkan Umur

\begin{tabular}{|l|c|c|}
\hline \multicolumn{1}{|c|}{ Umur } & Frekuensi & Persentase (\%) \\
\hline 16 Tahun & 50 & 5,3 \\
\hline 17 Tahun & 270 & 29 \\
\hline 18 Tahun & 520 & 56 \\
\hline 19 Tahun & 90 & 9,7 \\
\hline Total & 930 & 100 \\
\hline
\end{tabular}

Berdasarkan tabel 2 dapat diketahui bahwa sebagaian besar responden berusia 18 Tahun (56\%).

2. Analisa Bivariat

Tabel 3. Hubungan Pola Makan dengan Timbulnya Penyakit Gastritis

\begin{tabular}{|c|c|c|c|c|c|c|c|c|c|}
\hline \multirow[t]{3}{*}{ NO } & \multirow[t]{3}{*}{$\begin{array}{c}\text { POLA } \\
\text { MAKAN }\end{array}$} & \multicolumn{4}{|c|}{$\begin{array}{c}\text { TIMBULNYA } \\
\text { GEJALA } \\
\text { GASTRITIS }\end{array}$} & \multirow{2}{*}{\multicolumn{2}{|c|}{ TOTAL }} & \multirow[t]{3}{*}{$\begin{array}{c}\text { OR } \\
95 \%\end{array}$} & \multirow[t]{3}{*}{ P-Value } \\
\hline & & \multicolumn{2}{|c|}{ AKUT } & \multicolumn{2}{|c|}{ KRONIK } & & & & \\
\hline & & n & $\%$ & n & $\%$ & n & $\%$ & & \\
\hline 1 & Teratur & 270 & 75 & 70 & 12,3 & 340 & 36,6 & 21,429 & \\
\hline 2 & $\begin{array}{l}\text { Tidak } \\
\text { teratur }\end{array}$ & 90 & 25 & 50 & 87,7 & 590 & 63,4 & $\begin{array}{l}7,183- \\
63,928\end{array}$ & 0,000 \\
\hline \multicolumn{2}{|l|}{ Tota } & 360 & 100 & 570 & 100 & 930 & 100 & & \\
\hline
\end{tabular}

Berdasarkan tabel 3. Diketahui bahwa dari 930 orang responden terdapat $270(75 \%)$ responden dengan pola makan teratur yang menderita gastritis akut dan $70(12,3 \%)$ reponden pola makan teratur menderita gejala gastritis kronik. Sedangkan 90 (25\%) reponden dengan pola makan tidak teratur menderita gejala gastritis akun dan $500(87,7 \%)$ reponden dengan pola makan tidak teratur menderita gejala gastritis kronik.

Dari hasil uji statistik diperoleh nilai p-vae $0,000 \quad(\mathrm{p}<0.05)$. dengan demikian dapat disimpulkan bahwa Ho ditolak dengan kata lain ada hubungan yang signifikan antara pola makan dengan timbulnya gejala gastritis. Dengan nilai OR terbesar $21,429(7,183-$ 63,928 ) ini berarti responden dengan pola maan yang tidak teratur mempunyai peluang sebesar 3,820 kali untuk mengalami gejala gastritis kronik jika dibandingkan dengan responden yang memiliki pola makan yang teratur dengan derajat kepercayaan $95 \%$.

Tabel 4. Hubungan Jenis Makanan dengan Timbulnya Penyakit Gastritis

\begin{tabular}{|c|c|c|c|c|c|c|c|c|c|}
\hline \multirow[t]{3}{*}{ No } & \multirow[t]{3}{*}{$\begin{array}{c}\text { Jenis } \\
\text { Makanan }\end{array}$} & \multicolumn{4}{|c|}{$\begin{array}{c}\text { Timbulnya Gejala } \\
\text { Gastritis }\end{array}$} & \multirow{2}{*}{\multicolumn{2}{|c|}{ Total }} & \multirow[t]{3}{*}{$\begin{array}{l}\text { OR } \\
95 \%\end{array}$} & \multirow[t]{3}{*}{$\begin{array}{c}\text { P- } \\
\text { Value }\end{array}$} \\
\hline & & \multicolumn{2}{|c|}{ Akut } & \multicolumn{2}{|c|}{ Kronik } & & & & \\
\hline & & $\mathbf{n}$ & $\%$ & n & $\%$ & n & $\%$ & & \\
\hline 1 & Baik & 280 & 77,8 & 130 & 22,8 & 410 & 44,1 & 11,846 & \\
\hline 2 & $\begin{array}{l}\text { Kurang } \\
\text { baik }\end{array}$ & 80 & 22,2 & 440 & 77,2 & 520 & 55,9 & $\begin{array}{l}4,358- \\
32,204\end{array}$ & 0,000 \\
\hline \multicolumn{2}{|c|}{ Total } & 360 & 100 & 570 & 100 & 930 & 100 & & \\
\hline
\end{tabular}


Berdasarkan tabel 4 diketahui bahwa dari 930 orang responden terdapat $280(77,8 \%)$ responden dengan jenis makanan yang baik yang menderita gejala gastritis akut dan $130(22,8 \%)$ dengan jenis makanan baik yang menderita gejala gastritis kronik. Sedangkan $80(22,2 \%)$ responden dengan jenis makanan yang kurang baik menderita gejala gastritis akut dan $440(77,2 \%)$ reponden dengan jenis makanan kurang baik menderita gejala gastritis kronik.

Dari hasil uji statistik di dapatkan p 0,000 ( $\mathrm{p}<0,05)$ dengan demikian dapat disimpulka Ho ditolak dengan kata lain ada hubungan yang signifikan antara jenis makanan dengan timbulnya penyakit gastritis. Dengan nilai OR terbesar 11,846 (4,358-32,204) ini berarti bahwa responden dengan jenis makanan yang kurang baik mempunyai peluang sebesar 11,846 kali untuk menderita gejala gastritis kronik jika dibandingkan dengan responden dengan jenis makanan yang baik, dengan derajat kepercayaan $95 \%$.

1. Hubungan antara pola makan dengan timbulnya gejala gastritis

Hasil penelitian didapatkan bahwa sebagian besar responden yaitu sebanyak $87,7 \%$ responden memiliki pola makan yang tidak teratur dan mendeita gejala gastritis kronik. Hubungan pola makan dengan timbulnya geja;a gastritis elbih cenderung terjadi pada siswa yang memiliki aktivitas yang paat sehingga mengakibatkan pola makan menjadi tidak teratur, dengan p-value 0,000 .

Hasil penelitian ini sejalan dengan hasil penelitian Syurbani (2015), yang mendapatkan adanya hubungan antara pola makan dengan timbulnya penyakit gastritis. Responden dengan pola mkan tidak teratur mempunyai peluang 3,065 kali untuk mengalami kejadian klinis gastritis dibandingkan dengan responden dengan pola makan teratur.

Pola makan yang benar adalah pola makan yang teratur setiap harinya dan makan dalam waktu dan jam yang sama setiap harinya. Aktivitas yang begitu padat juga dapat membuat pola makan menjadi tidak teratur. Karena pola makan yang tidak teratur dapat menyebabkan inflamasi pada mukosa lambung.

2. Hubungan antara jenis makanan dengan timbulnya gejala gastritis

Berdasarkan hasil penelitian di dapatkan sebanyak $77,2 \%$ orang responden yang mengkonsumsi jenis makanan yang kurang baik yang menderita gejala gastritis. Hal ini dikarenakan siswa sering mengkonsumsi makanan yang mengandung asam dan pedas sehingga menderita gastritis, hal ini ditandai dengan nilai $p$-value 0,000 yang berarti ada hubungan yang signifikan antara jenis makanan yang dikonsumsi engan timbulnya gejala gastritis.

Beberapa makanan berbumbu yang mengandung rempahrempah seperti makanan yang mengandung lada, cuka dapat 
menyebabkan gejala yang mengarah pada gastriitis. Makanan pedas dapat merangsang produksi asam lambung, semakin banyak mengkonsumsi makanan berbunbu dan pedas, semakin besar terjadinya gastritis (Price, 2012)

\section{KESIMPULAN}

Dari penelitian ini didapatkan bahwa sebagian besar responden mengalami gastritis kronik yaitu sebanyak $61,3 \%$. Hasil ini dibuktikan dengan nilai $\mathrm{p}$-value $0,000 \quad(<0,05)$ sehingga dapat disimpulkan terdapat hungan yang signifikan antara pola makan dan jenis makanan terhadap terjadinya gejala gastritis.

Berdasarkan hasil yang didapatkan tersebut besar harapan kami untuk pihak sekolah - sekolah untuk dapat menyediakan tempat makan atau kantin yang sehat dalam menu makanannya dan bervariasi.

\section{DAFTAR PUSTAKA}

Hidayat, AA. 2007. Metode Penelitian Keperawatan dan Teknik Analisis Data. Salemba Medika: Jakarta.

Hadi, S. 2012. Gastroenterologi. Penerbit Alumni: Bandung.

Inayah, I. 2014. Asuhan Keperawatan Pada Klien Dengan Gangguan Sistem Pencernaan. Salemba Medika: Jakarta.

Moehyi, Sjahmien. 2012. Pengaturan Makanan dan Diit untuk Penyembuhan Penyakit. PT Gramedia: Jakarta.

Nurachman, Elly. 2010. Nutrisi Dalam Keperawatan.

Price, A. 2012. Konsep Klinis proses Penyakit.

Rani, Aziz. 2010. Gastroenterologi Hepatologi. CV Sagung Seto: Jakarta.

Sudijono, A. 2014. Pengantar Statistik Kesehatan. Pers: Jakarta.

Syurbani. 2017. Hubungan Pola Makan, Kebiasaan merokok dan Stress Psikis pada siswa - siswa yang akan menghadapi UAN. Tesis. 